ORIGINAL ARTICLE

\title{
Detection of aneuploidies by paralogous sequence quantification
}

\author{
S Deutsch, U Choudhury, G Merla, C Howald, A Sylvan, S E Antonarakis
}

J Med Genet 2004;41:908-915. doi: 10.1136/jmg.2004.023184

See end of article for authors' affiliations

....................

Correspondence to: Professor Stylianos E Antonarakis, Department of Genetic Medicine and Development, University of Geneva Medical School, GE 1211, Geneva, Switzerland; Stylianos. antonarakis@medecine. unige.ch

Revised version received 1 June 2004

Accepted for publication 6 July 2004
Background: Chromosomal aneuploidies are a common cause of congenital disorders associated with cognitive impairment and multiple dysmorphic features. Pre-natal diagnosis of aneuploidies is most commonly performed by the karyotyping of fetal cells obtained by amniocentesis or chorionic villus sampling, but this method is labour intensive and requires about 14 days to complete.

Methods: We have developed a PCR based method for the detection of targeted chromosome number abnormalities termed paralogous sequence quantification (PSQ), based on the use of paralogous genes. Paralogous sequences have a high degree of sequence identity, but accumulate nucleotide substitutions in a locus specific manner. These sequence differences, which we term paralogous sequence mismatches (PSMs), can be quantified using pyrosequencing technology, to estimate the relative dosage between different chromosomes. We designed 10 assays for the detection of trisomies of chromosomes 13, 18, and 21 and sex chromosome aneuploidies.

Results: We evaluated the performance of this method on 175 DNAs, highly enriched for abnormal samples. A correct and unambiguous diagnosis was given for 119 out of 120 aneuploid samples as well as for all the controls. One sample which gave an intermediate value for the chromosome 13 assays could not be diagnosed.

Conclusions: Our data suggests that PSQ is a robust, easy to interpret, and easy to set up method for the diagnosis of common aneuploidies, and can be performed in less than $48 \mathrm{~h}$, representing a competitive alternative for widespread use in diagnostic laboratories.
C hromosome number abnormalities or aneuploidies were first recognised as a cause of human disease in 1959, with the detection of an extra copy of chromosome 21 in children affected with Down syndrome (DS). ${ }^{12}$ Since then many numerical chromosome abnormalities have been characterised, and their overall frequency in all human populations is estimated to be around 1/200 live births. Autosomal trisomies of chromosomes 13 (Patau syndrome), 18 (Edward syndrome), and 21 (DS), and sex chromosome numerical abnormalities (45,X, 47,XXY, 47,XYY, and 47,XXX) account for the vast majority of aneuploidies encountered. DS is the most common chromosomal disorder, resulting in severe mental retardation and multiple dysmorphic features. It affects approximately 1/750 live births in all ethnic groups, but high risk pregnancies can be determined through analysis of serum markers and ultrasonographic screening, with maternal age as a risk factor. ${ }^{4}$

Since the early 1970s prenatal diagnosis for chromosomal disorders has been offered to women with high risk pregnancies, by performing karyotype analysis on fetal cells obtained by amniocentesis or chorionic villus sampling. Even though karyotyping remains the gold standard for chromosome analysis, it has considerable disadvantages, since it is labour intensive, expensive, and takes on average 14 days for the results to be reported. ${ }^{4}$ These drawbacks have encouraged the development of faster and more efficient techniques for the diagnosis of targeted chromosomal anomalies, such as interphase fluorescence in situ hybridisation (FISH) ${ }^{5}$ and quantitative fluorescence polymerase chain reaction (QFPCR). ${ }^{67}$ Both of these techniques are now routinely performed in many diagnostic laboratories in order to provide a rapid (48 h on average) preliminary diagnosis. ${ }^{4}$ Interphase FISH is also labour intensive, since it requires counting a considerable number of nuclei (50-100) in order to be reliable. QF-PCR, which is based on the amplification of polymorphic microsatellite repeats, is less costly and has the advantage that many samples can be treated in parallel. ${ }^{89}$ However, since individuals are not heterozygous at all polymorphic sites, it requires the analysis of multiple markers (usually four or five) per chromosome in order to obtain at least two informative markers for each individual. This involves setting up and optimising multiplex PCR reactions, which can be a lengthy and complex process.

The completion of the human genome sequence ${ }^{10}{ }^{11}$ has provided an extensive catalogue of sequence features that can be exploited for the design of new diagnostic strategies. In this paper we propose and validate a new PCR based diagnostic approach based on the use of paralogous sequences located on different chromosomes. Paralogous sequences have a high degree of sequence identity, but they accumulate nucleotide substitutions over time in a locus specific manner. The principle of the method is based on designing a single pair of primers to co-amplify paralogous sequences located on different chromosomes. The resulting PCR products (of identical size) will contain a number of internal sequence differences (paralogous sequence mismatches or PSMs) that are specific to each locus and are not polymorphic. Quantification of the PSM position can be used to determine the relative dosage of the chromosomes in which the paralogous sequences are located and thus detect the presence of chromosome number abnormalities.

We applied this method, which we term paralogous sequence quantification (PSQ), to 175 DNAs, of which 120 contained a common aneuploidy. We show that it is a

Abbreviations: DS, Down syndrome; $\mathrm{FISH}$, fluorescence in situ hybridisation; PSMs, paralogous sequence mismatches; PSQ, paralogous sequence quantification; QF-PCR, quantitative fluorescence polymerase chain reaction 
reliable, simple, and high throughput alternative for the diagnosis of targeted aneuploidies.

\section{METHODS \\ Samples}

DNA samples from 50 trisomy 21 individuals that had been previously collected with informed consent in our laboratory were used for this study. Specific authorisation was requested from the ethics committee of the Geneva University Hospitals for use of the DNA samples in this particular project. Fifteen fibroblast cell cultures from individuals with various chromosomal abnormalities were purchased from the Coriell Cell Repositories (GM03330, GM02948, GM00526, GM03538, GM02732, GM01359, GM00734, GM00143, GM03102, GM01250, GM09326, GM11337, GM00857, GM01176, GM10179). Sixty DNA samples of individuals carrying trisomies of chromosomes 13 and 18, and various sex chromosome abnormalities, were provided by Genzyme (Cambridge, MA, USA). Finally, 50 normal individuals from the CEPH collection were used as additional controls.

Genomic DNA was prepared with either the PUREGENE whole blood kit (Gentra Systems, Minneapolis, MN, USA) or the QIAamp kit (Qiagen, Hilden, Germany).

\section{Paralogous sequence quantification (PSQ)}

PCR reactions with the selected primer pairs (table 1) were set up in a total volume of $25 \mu \mathrm{l}$ containing $20 \mathrm{ng}$ of genomic DNA, 5 pmol of each primer, and $200 \mu \mathrm{mol} / \mathrm{l}$ of dNTPs. We used $1.25 \mathrm{U}$ of a standard Taq polymerase (Amersham Biosciences, Little Chalfont, Buckinghamshire, UK) or alternatively a ready made $2 \times$ PCR mastermix containing dUTP and $\mathrm{N}$-uracil glycosylase (Eurogentec, Seraing, Belgium) with varying levels of $\mathrm{MgCl}_{2}$ and DMSO depending on the assay (table 1).

PCRs were carried out on a $\mathrm{T}$ gradient thermocycler (Biometra, Göttingen, Germany), and cycling conditions consisted of a 2 min step at $50^{\circ} \mathrm{C}$, and 10 min denaturation at $94^{\circ} \mathrm{C}$. This was followed by 10 cycles of "touchdown PCR" with a $20 \mathrm{~s}$ denaturation step at $94^{\circ} \mathrm{C}$, a $20 \mathrm{~s}$ annealing step starting at $57^{\circ} \mathrm{C}$ and decreasing by $-0.5^{\circ} \mathrm{C}$ per cycle, and an extension step at $72^{\circ} \mathrm{C}$ for $20 \mathrm{~s}$. The final 30 cycles were as before, but with a constant annealing temperature of $52^{\circ} \mathrm{C}$, followed by a final elongation step of $72^{\circ} \mathrm{C}$ for $5 \mathrm{~min}$.

PCR products were purified, and annealed to an internal sequencing primer close to the PSM site to be quantified. The purification and pyrosequencing steps were performed following the instructions of the manufacturer (Biotage $A B$, Uppsala, Sweden).

\section{Data analysis}

The Pyrosequencing software (PSQ 96 MA software; www. biotage.com) directly outputs a quantitative value for the proportion of each PSM present in the PCR product. We used the percent of the "query" chromosome as our statistic for all calculations. To determine the range of values that could be confidently diagnosed for every assay we calculated the $99 \%$ confidence for the distribution of control and affected individuals (bimodal distribution). Any sample with a value outside these limits was considered uncertain. Uncertain samples were treated either as false positives or as false negatives according to the known karyotypes, and this was used to estimate the sensitivity and specificity of each test using standard approaches. ${ }^{12}$

In order to combine the two assays for each type of aneuploidy, we first normalised each distribution so that the average percent of the query chromosome for the control individuals was 50 (the expected outcome). We then calculated the mean of the two assays for each sample.

In order to determine the reproducibility of our assays, we randomly selected a control and an affected sample for each autosomal aneuploidy, and a male and a female sample for the $\mathrm{X} v \mathrm{Y}$ and $\mathrm{X} v$ autosomal (A) assays. We performed 12 replicates for each sample for each assay: four on the same run with the same PCR mix, four on a second day with the same PCR mix as the first day, and four on a third day with a different batch of PCR mix and performed by a different operator. We calculated the coefficient of variation for same day, same PCR batch measurements (CVI), different day, same PCR batch measurements (CV2), and different day, different PCR batch measurements (CV3).

\section{RESULTS}

\section{Assay design}

In order to design PSQ assays, paralogous sequences located on different chromosomes must first be identified. One of the sequences must map to the chromosome of interest (or query chromosome, for example chromosome 21) and the second to any other autosomal chromosome (the reference chromosome).

To identify such paralogous sequences, all the known exons of chromosomes 13, 18, 21, and X (http://www. ensembl.org/) were batch blasted against the human genome. We selected matches with high scores (usually $>350$ ) and very low $\mathrm{E}$ values $\left(<10^{-40}\right)$ where only two hits were observed: one to the query chromosome and the second elsewhere on another autosomal chromosome (fig lA).

The second step of the method involves the quantification of single nucleotide differences between PSMs. For this we chose the Pyrosequencing ${ }^{13}$ method which has been previously shown to be highly quantitative. ${ }^{14-17}$

To design pyrosequencing assays, we took the selected BLAST alignments for each of the query chromosomes (fig 1B) and manually built a consensus sequence, which

Table 1 PCR primers and conditions

\begin{tabular}{|c|c|c|c|c|c|}
\hline Test & Gene ID & $\begin{array}{l}\text { PCR; [Mg]; } \\
\text { DMSO }\end{array}$ & F primer & $\mathbf{R}$ primer & S primer \\
\hline Hsa 21 a & ITSN & $\mathrm{A} ; 3$ & ATTTATTGCCATGTACACTT & bGAATCTITAAGCCTCACATAG & ACCAAGAAAGATGGTGAC \\
\hline Hsa $21 b$ & GABPA & $A ; 3$ & bCTIACTGATAAGGACGCTC & CTCATAGTTCATCGTAGGCT & TCACCAACCCAAGAAA \\
\hline Hsa $13 a$ & NUFIPI & $\mathrm{E} ; 1.5$ & bGCTGAGCCGACTAGTGATT & AAGGGAAGCGAGGACGTAA & GGAAGCGAGGACGTA \\
\hline Hsa $13 b$ & STK24 & $\mathrm{A} ; 1.5$ & CGCTCTCGTCTGACATTI & bTCAGACATITITAGGTGG & CATTTGTTTGGAATCGT \\
\hline Hsa $18 a$ & KIAA1328 & $A ; 3 ; 5 \%$ & CGAAGGAAATGTCAGATCAA & bGACTCCATGGAGATTGAAG & TGTCAGATCAAGACACA \\
\hline Hsa $18 b$ & WBPI1 & A; 3 & bGGAGGGACGGGAAGTAGAG & GTGAAGAAGCAGTGGATGTGCC & CAGAATCATCTTCATCAT \\
\hline Hs XYa & $A R S D$ & $\mathrm{E} ; 3$ & CGCCAGCAATGGATAC & bTGCAAAAGTGGTTTCGTTC & GGCCCTTCAGTGGA \\
\hline $\mathrm{Hs} \mathrm{XYb}$ & TGIF2LX & $\mathrm{E} ; 3$ & bAAGACAGCCCGGCGAAGA & ATTCCGGGAGAATGCGTCTGC & TGATAAACCAGTTAGAAATC \\
\hline $\mathrm{Hs}$ XAa & TAFOL & $\mathrm{E} ; 3$ & bTGCCTAATGTITTGTGATT & GACCCAAAACTACCTGTC & GTAAAACCCAACTG \\
\hline $\mathrm{Hs} X A b$ & JM5 & $\mathrm{E} ; 3$ & CCCTGTGTGTCTCTAAACCAGC & bGGTGGCAGGGTCAGT & GAAACTGGTGGAGCTG \\
\hline
\end{tabular}

Gene ID refers to HUGO names for all the query genes. PCR refers to the PCR conditions used: A indicates that Amersham Biosciences and E indicates that Eurogentec PCR buffers and Taq polymerase were used. 3 or 1.5 indicates the final concentration of $\mathrm{MgCl}_{2}$ and $5 \%$ indicates the final concentration ( $\mathrm{v} / \mathrm{v}$ ) of DMSO. $b$ at the start of the primers indicates 5 'biotinylated primer. $F, R$, and $S$ refer to forward, reverse, and sequencing primers, respectively. 


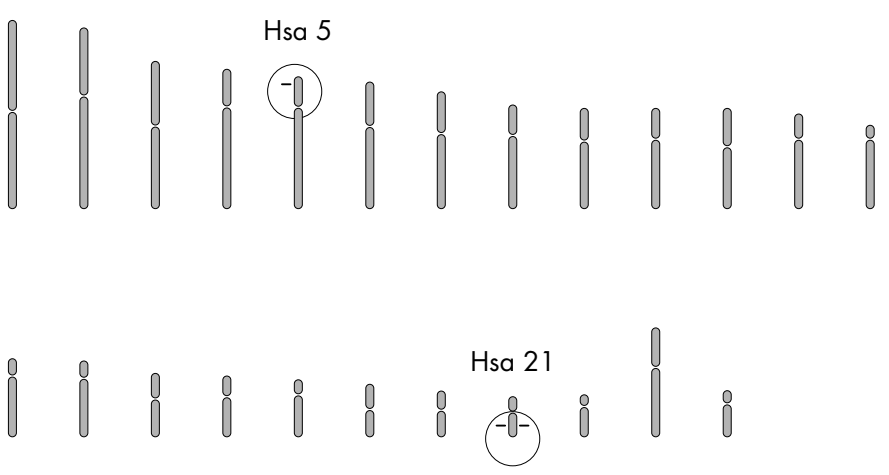

B

Hsa 21 aatttattgcatgtacacttacgagagttctgagcaaggagatttaaccttcagcaag Hsa 5 aiattattgccatgtacactitaccagagttctgagcaaggagatttaaccttcagcag

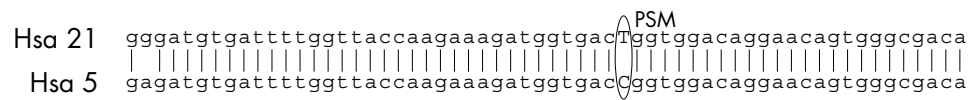

Hsa 21 aggccggagtcttccttctaactaitgtgaggcttaaagattcaigag

Hsa 5 aggccggagtcttccctctaactaitgtgaggcttaagattcaigag
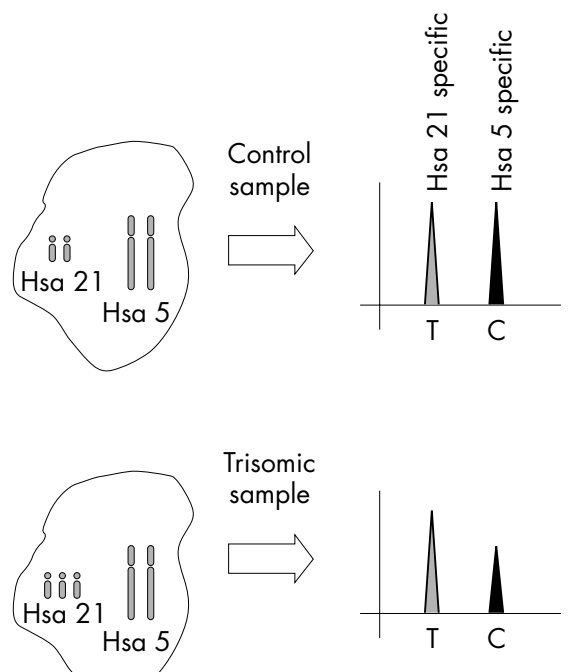

Figure 1 (A) Ideogram of human chromosomes. The black horizontal bars highlighted by circles show the positions of paralogous sequences in the human genome. Only sequences that were present only twice with a high degree of homology were used. (B) Typical alignment between paralogous sequences used for designing PSQ assays. Dotted boxes indicate the position of primers, and the encircled position shows the paralogous sequence mismatch used for quantification. (C) Principle of the method. If a cell contains two copies of chromosome 5 and two copies of chromosome 21 , one expects to see a ratio of $1: 1$ at the PSM position. When three copies of chromosome 21 are present this ratio should be 1.5:1.

was entered into Oligo 3 software (Molecular Biology Insights, West Cascade, CO, USA) to obtain a suitable pair of primers perfectly matching both chromosomes (to minimise differences in the efficiencies of amplification) and spanning at least one PSM. Quantification of the PSM position by pyrosequencing can be used to determine the relative dosage of the query and reference chromosomes (fig 1C).

For the detection of sex chromosome abnormalities, we designed two types of assays: first, $\mathrm{X} v \mathrm{Y}$ assays to quantify the ratio between the $\mathrm{X}$ and the $\mathrm{Y}$ chromosomes (using a paralogous sequence present in the $\mathrm{X}$ and $\mathrm{Y}$ chromosomes), and second, $\mathrm{X} v$ autosomal assays to obtain the ratio between the $\mathrm{X}$ and any autosomal chromosome. The theoretically expected values (table 2) show that this strategy allows the identification of all common aneuploidies.

Table 2 Expected values

\begin{tabular}{|c|c|c|c|c|}
\hline \multicolumn{2}{|c|}{$\begin{array}{l}\text { Autosomal } \\
\text { trisomies }\end{array}$} & \multicolumn{3}{|c|}{ Sex chromosome abnormalities } \\
\hline Status & $\begin{array}{l}\text { Expected } \\
\text { value }(\%)\end{array}$ & Karyotype & $\begin{array}{l}\text { Expected value } X \\
\text { v A assay }(\%)\end{array}$ & $\begin{array}{l}\text { Expected value } X \\
v Y \text { assay }(\%)\end{array}$ \\
\hline Control & 50 & $45, \times 0$ & 33 & 100 \\
\hline \multirow{5}{*}{ Trisomic } & 60 & $46, X X$ & 50 & 100 \\
\hline & & $46, X Y$ & 33 & 50 \\
\hline & & $47, X X Y$ & 50 & 66 \\
\hline & & $47, X Y Y$ & 33 & 33 \\
\hline & & $47, X X X$ & 60 & 100 \\
\hline
\end{tabular}

Expected theoretical values for all assays are expressed as percent of query chromosome.

\section{Assay selection}

We originally designed four to five assays per chromosomal abnormality that were pre-screened with a panel of eight control and eight aneuploid samples. Each assay was tested with a number of PCR conditions (varying concentrations of $\mathrm{MgCl}_{2}$ and DMSO, and two types of buffer as described in the Methods section). From this, we selected assays for each chromosomal abnormality based on the following criteria: (a) the PSM quantification in control individuals should be close to $50 \%$, indicating that both alleles amplify with equal efficiency; (b) there should be a clear, non-overlapping discrimination between control and aneuploid samples; and (c) there should be the least possible deviation from the mean.

Only a subset of the assays fulfilled these conditions, and most of the assays were sensitive to the PCR condition used (data not shown). Ultimately we selected the best two assays for each chromosomal abnormality for further validation.

\section{Assay results}

We analysed the performance of the 10 independent tests designed to detect trisomies of chromosomes 13, 18, and 21 as well as sex chromosome aneuploidies. The means (we used percent of query chromosome as our statistic) and standard deviations for all of the assays are shown in table 3.

Typical results of normal and affected samples for each assay are shown in fig 2 . In eight out of the 10 assays the observed average values corresponded or were very close to the theoretically expected values (tables 2 and 3 ), and for the two remaining assays (Hsa $13 \mathrm{~b}$ and Hsa $2 \mathrm{lb}$ ) there was an approximate $10 \%$ downwards shift for both the control and affected group, which did not affect the performance of the tests. The sensitivity and specificity were similar across all the assays (table 3 ), with no false positive or false negative calls, 


\begin{tabular}{|c|c|c|c|c|c|c|}
\hline Autosomal assays & Hsa 13a & Hsa $13 b$ & Hsa 18a & Hsa $18 b$ & Hsa 21a & Hsa $21 \mathrm{~b}$ \\
\hline Mean control & 49.6 & 43.4 & 51.3 & 48.7 & 51.9 & 41.8 \\
\hline SD control & 1.6 & 1.7 & 1.8 & 1.6 & 1.4 & 1.2 \\
\hline Mean trisomic & 58.7 & 52.5 & 60.6 & 55.9 & 60.2 & 51.4 \\
\hline SD trisomic & 2.3 & 1.4 & 1.5 & 0.9 & 1.3 & 1.4 \\
\hline Number of samples & 93 & 91 & 90 & 92 & 107 & 110 \\
\hline Number of uncertain samples & 6 & 7 & 7 & 6 & 8 & 5 \\
\hline Sensitivity & 0.86 & 0.92 & 1.00 & 0.93 & 0.92 & 0.96 \\
\hline Specificity & 1.00 & 0.97 & 0.90 & 0.96 & 0.93 & 0.95 \\
\hline Sex chromosome assays & $\mathrm{Hs} \mathrm{X} v \mathrm{Ya}$ & $\mathrm{Hs} \mathrm{X} v \mathrm{Yb}$ & $\mathrm{Hs} \mathrm{X} v \mathrm{Aa}$ & $\mathrm{Hs} X \vee \mathrm{Ab}$ & & \\
\hline Mean $46, X Y$ & 50.5 & 53.9 & 31.1 & 36.1 & & \\
\hline SD $46, X Y$ & 1.7 & 1.0 & 1.8 & 1.3 & & \\
\hline Mean value $46, X X$ & 91.3 & 97.4 & 44.0 & 48.8 & & \\
\hline SD $46, X X$ & 2.4 & 0.7 & 2.0 & 1.7 & & \\
\hline Number of samples & 93 & 93 & 93 & 93 & & \\
\hline
\end{tabular}

but with on average $7 \%$ of samples falling outside the set confidence thresholds, thus precluding a diagnosis.

Since we had two independent assays for each aneuploidy, we integrated the results of both tests for each sample to generate a combined distribution. This resulted in a significant improvement in the separation between control and affected individuals, as seen by the greater sensitivities and specificities across all the tests (table 4 and fig 3 ) and $99 \%$ of the samples being unambiguously diagnosed.

Through out the study, 12 DNA samples repeatedly failed to amplify for at least one of the assays, and so these samples were not considered further.

\section{Assays for autosomal aneuploidies}

For trisomies of chromosomes 18 and 21, we tested 89 and 105 DNAs, respectively, and obtained a correct and unambiguous diagnosis in all cases (table 4). We thus correctly identified all 29 trisomy 18 samples and 47 trisomy 21 samples present in the cohort. Concerning the assays for trisomy 13, 91 DNAs were analysed, and out of these an unambiguous diagnosis was obtained for 90 samples. The status of one sample remained uncertain, since its combined value was outside the $99 \%$ confidence intervals. We repeated the two trisomy 13 assays for this DNA, which again resulted in an ambiguous result, and thus the sample could not be diagnosed. It is possible that this DNA originates from an individual mosaic for trisomy 13, but since DNAs had been fully anonymised prior to the study, we could not re-analyse the original karyotype.

\section{Assays for sex chromosome aneuploidies}

We analysed 93 DNAs for combined X $v$ Y assays and obtained a very clear separation between the four groups defined by the ratio between the $\mathrm{X}$ and $\mathrm{Y}$ chromosomes (fig 3B). In particular, the separation between the male group and the group containing the females $(46, \mathrm{XX}, 45, \mathrm{X}$, and $47, \mathrm{XXX}$, all of which have $100 \%$ of chromosome X) was very large, but this was expected and reflects the theoretical outcomes (table 1). Nevertheless, since very few XXY and XYY individuals were present in the study, additional samples are required in order to establish the precise performance of these tests.

For the Xv A combined assays, we analysed 91 samples out of which two samples gave intermediate values that could not be diagnosed. However, since these tests are partially redundant with the $\mathrm{X} v \mathrm{Y}$ assays, only one sample could not be fully resolved. One of the samples that had given a value of $41 \%$ in the $\mathrm{X} v \mathrm{~A}$ assay (hence an intermediate value between one and two $\mathrm{X}$ chromosomes), gave a value of $52 \%$ in the $\mathrm{X} v$
$\mathrm{Y}$ assay and thus was unambiguously diagnosed as a normal male. The second sample with an inconclusive diagnosis ( $\mathrm{X} v$ A combined value of $43 \%$ ) had given a value of $89 \%$ for the $X$ $v \mathrm{Y}$ assay, and therefore it was not possible to discriminate between a 46,XX or a 45,X0 diagnosis. We thus repeated the two $\mathrm{X} v \mathrm{~A}$ tests and obtained a combined value of $48 \%$ showing that individual is $46, \mathrm{XX}$ in concordance with the karyotype.

\section{Reproducibility}

To estimate the reproducibility of individual measurements, we selected a control and an affected sample for each aneuploidy (for the $\mathrm{X} v \mathrm{Y}$ and $\mathrm{X} v$ A assays we picked individuals of different gender) and performed 12 replicates as detailed in the Methods section. The results shown in table 5 demonstrate a high reproducibility for all of the assays, with a low coefficient of variation between same day and same batch replicates $(0.7-4.3 \%$ of the mean), and for some assays a larger variation for inter batch replicates (up to $6.2 \%$ ). These results indicate that some of the tests are sensitive to precise PCR conditions and thus, to improve the reliability of the tests, it might be advisable to work with frozen aliquots of a previously validated PCR mix containing the primers, buffer, and dNTPs.

\section{DISCUSSION}

In this study we present the PSQ method as an alternative approach for the rapid and efficient detection of targeted aneuploidies. Ten different assays, designed for the identification of autosomal trisomies of chromosomes 13, 18, and 21 and sex chromosome number abnormalities, were tested. We performed a retrospective study on 175 DNAs that were selected to include a relatively large number of aneuploid samples in order to evaluate the sensitivity and specificity of the tests.

The performance of single assays was characterised by no false negative or false positive calls, but a certain number of samples ( $7 \%$ on average) fell outside the $99 \%$ confidence intervals, and for these an unambiguous diagnosis could not be established. When combining the two tests for each chromosomal disorder, there was a significant improvement in the separation between control and affected samples, resulting in increased sensitivities and specificities across all tests, and the correct identification of 118 out of 120 abnormal samples present in the study. The diagnoses in the remaining two samples were inconclusive after the first run and were subsequently re-tested. This allowed an unambiguous diagnosis for one of the two, while the status of the second sample remained uncertain. It is possible this 

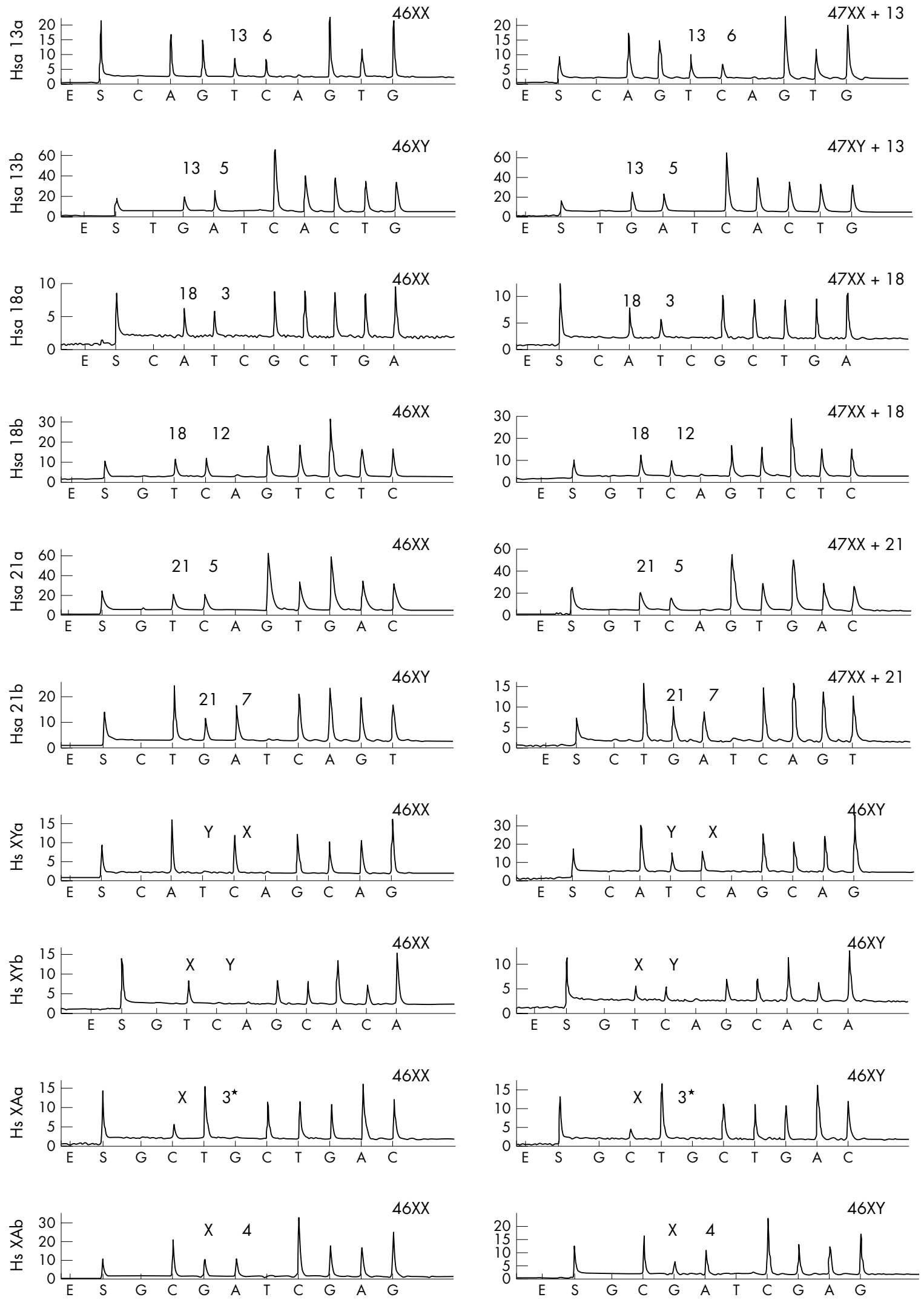

Figure 2 Typical results ("pyrograms") of control and affected individuals for all assays (for $X v Y$ and $X v A$ assays males $v$ females are shown). The name of each assay is given on the left and the karyotypes on the top right corner of each panel. The PSM position is indicated by the numbers above the peaks in each graph, which correspond to the chromosomes in which the paralogous sequence is located. 

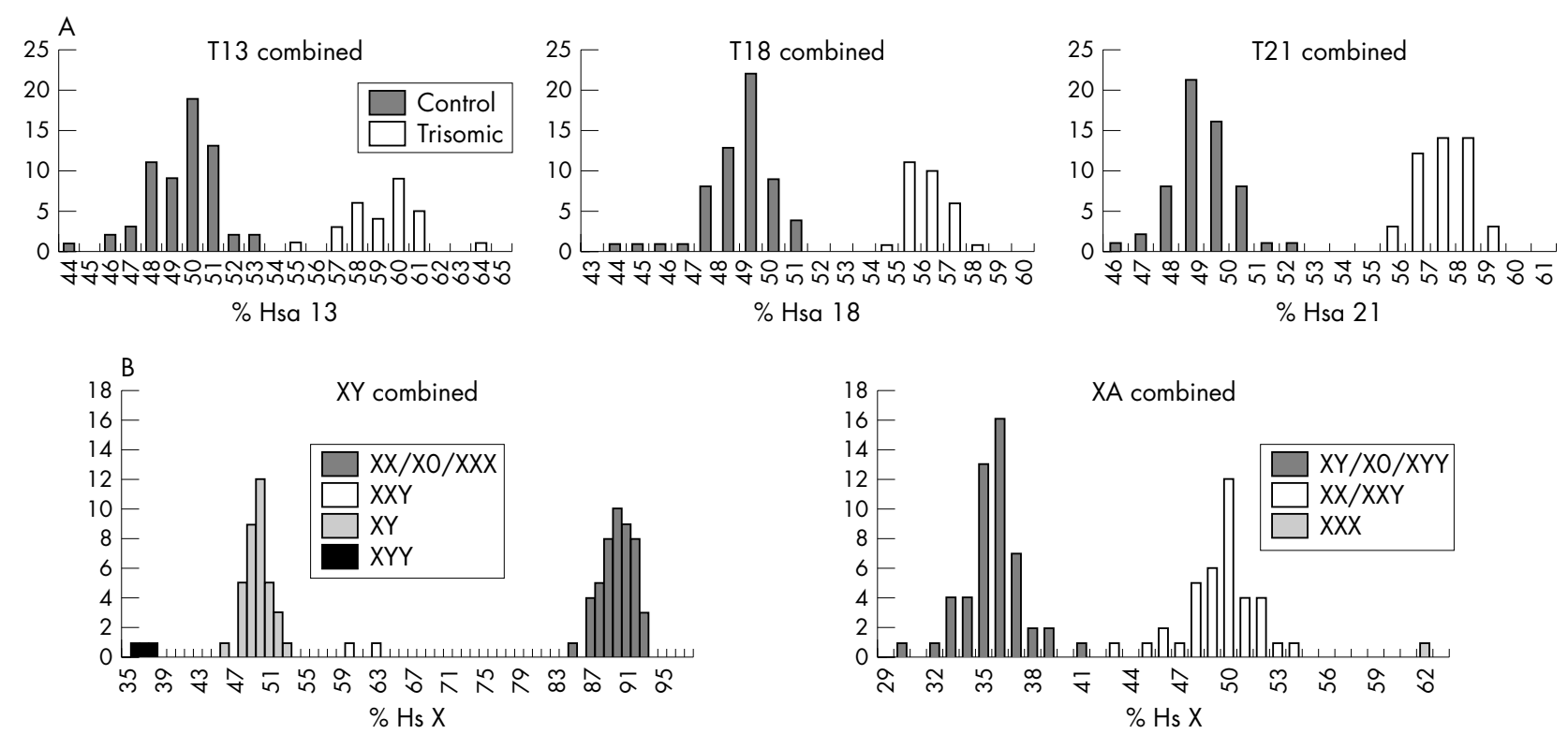

Figure 3 (A) Combined distributions of the autosomal assays. (B) Distributions of the $X v Y$ and $X v A$ assays. The $x$ axes represent the percent of the query chromosome and the $y$ axes the frequency of each class.

DNA originated from an individual with trisomy 13 mosaicism, but this could not be confirmed.

Eight out of the 10 assays gave average values that were very close to the theoretically expected value. This shows that our strategy of using co-amplification of paralogous sequences with a single pair of primers that match perfectly at both loci, resulted in almost identical amplification efficiencies, and importantly, that end point measurement using the Pyrosequencing method is a quantitative and reliable technique consistent with previously published results. ${ }^{14-17}$ Selected samples for each assay were measured 12 times in order to evaluate the reproducibility of the tests. The intra and inter run variation between measurements was low when the PCR mixes were from the same batch. Inter batch variances were higher for some assays, suggesting that even small differences in the PCR mix resulting from inaccurate pipeting can have an effect. Our results suggest that in order to optimise the reliability of the procedure it might be necessary to make batches of PCR mix that can be tested and stored prior to use.

The first generation design of this test requires 10 separate PCRs per sample, which significantly reduces the sample throughput and increases the probability of handling errors. However, since the Pyrosequencing technology allows for a certain degree of multiplexing, subsequent improved assays should consist of no more than three or four PCRs per sample. Even with the current protocol, a single operator can

Table 4 Specificity and sensitivity of combined assays

\begin{tabular}{lllc}
\hline Assays & $\begin{array}{l}\text { Hsa 13 } \\
\text { combined }\end{array}$ & $\begin{array}{l}\text { Hsa 18 } \\
\text { combined }\end{array}$ & $\begin{array}{l}\text { Hsa 21 } \\
\text { combined }\end{array}$ \\
\hline Mean control & 50 & 50 & 50 \\
SD control & 1.27 & 1.11 & 0.9 \\
Mean trisomic & 59.8 & 58.3 & 59.6 \\
SD trisomic & 1.32 & 1.11 & 1.05 \\
Number of samples & 91 & 89 & 105 \\
Number of uncertain & 1 & 0 & 0 \\
samples & & 1 & 1 \\
Sensitivity & 0.97 & 1 & 1 \\
Specificity & 1 & 1 & \\
\hline
\end{tabular}

handle at least 30-40 samples a day and report results in less than $48 \mathrm{~h}$, which should cover the needs of most diagnostic laboratories.

Alternative molecular methods for the diagnosis of aneuploidies have been recently developed. ${ }^{4}{ }^{18}$ PCR based methods such as QF-PCR, ${ }^{6-9}$ multiple amplifiable probe hybridisation, ${ }^{19}$ multiplex probe ligation assay, ${ }^{20}{ }^{21}$ and PSQ (present study) all have the advantage of being inexpensive and efficient in terms of labour and high throughput. QFPCR, which is based on the use of polymorphic markers, is by far the most established of all the PCR based techniques, however, it has a number of shortcomings, since some individuals can be homozygous at all sites and the informativeness of markers can vary across different populations. Despite these problems, QF-PCR has been successfully implemented in several diagnostic laboratories ${ }^{82}$ and protocols using single nucleotide polymorphisms are currently being developed. Multiple amplifiable probe hybridisation and multiplex probe ligation assay (both based on size specific probe design, co-amplification, and size separation by capillary electrophoresis) do not make use of polymorphic markers and in principle work on all individuals. These two approaches have the advantage of allowing the simultaneous analysis of up to 40 loci using size specific probes that can be efficiently resolved by capillary electrophoresis, but initial results have shown that up to eight probes per chromosome are needed to obtain reliable results. ${ }^{20}$

The major drawback of all PCR based tests is that they are targeted to specific regions of the genome, hence rare chromosomal abnormalities and balanced translocations can not be detected. In addition, low level mosaicism, which can have significant clinical consequences, is difficult to detect with any DNA based rather than cell based method.

Non-PCR based technologies such as comparative genome hybridisation have recently shown encouraging results ${ }^{23} 24$ and the development of high resolution BAC arrays will surely become a powerful tool for the molecular diagnosis of DNA copy number abnormalities. However, current protocols are considerably labour intensive and costly, and hence their application in routine diagnostic protocols is not yet feasible.

The important debate of whether molecular tests should be used as stand alone tests (thus replacing karyotyping 
Table 5 Reproducibility of assays

\begin{tabular}{|c|c|c|c|c|c|c|}
\hline \multirow{2}{*}{$\begin{array}{l}\text { Assays } \\
\text { Autosomal }\end{array}$} & \multicolumn{3}{|l|}{ Control } & \multicolumn{3}{|c|}{ Aneuploid } \\
\hline & $\mathrm{CV} 1$ & CV2 & CV3 & CV1 & CV2 & CV3 \\
\hline Hsa 13a & 0.020 & 0.023 & 0.024 & 0.023 & 0.020 & 0.027 \\
\hline Hsa $13 b$ & 0.024 & 0.024 & 0.023 & 0.014 & 0.017 & 0.015 \\
\hline Hsa $18 a$ & 0.023 & 0.028 & 0.024 & 0.036 & 0.044 & 0.045 \\
\hline Hsa $18 b$ & 0.011 & 0.013 & 0.014 & 0.020 & 0.024 & 0.018 \\
\hline Hsa 21 a & 0.012 & 0.015 & 0.025 & 0.020 & 0.015 & 0.027 \\
\hline \multirow[t]{2}{*}{ Hsa $21 b$} & 0.023 & 0.028 & 0.046 & 0.041 & 0.043 & 0.041 \\
\hline & \multicolumn{3}{|l|}{ Male } & \multicolumn{3}{|l|}{ Female } \\
\hline Sex chromosome & $\overline{\mathrm{CV} 1}$ & CV2 & CV3 & $\overline{\mathrm{CV} 1}$ & CV2 & CV3 \\
\hline $\mathrm{Hs}_{\mathrm{S}} \mathrm{X} \vee \mathrm{Ya}$ & 0.042 & 0.030 & 0.062 & 0.007 & 0.007 & 0.009 \\
\hline $\mathrm{Hs} X \vee \mathrm{Yb}$ & 0.022 & 0.017 & 0.029 & 0.016 & 0.012 & 0.034 \\
\hline $\mathrm{Hs} \mathrm{X} \vee \mathrm{Aa}$ & 0.033 & 0.032 & 0.034 & 0.036 & 0.044 & 0.039 \\
\hline $\mathrm{H} s \mathrm{X} \vee \mathrm{Ab}$ & 0.038 & 0.044 & 0.058 & 0.021 & 0.040 & 0.060 \\
\hline \multicolumn{7}{|c|}{$\begin{array}{l}\text { Values indicate the coefficient of variation for each of the assays. CV1 refers to same run, same PCR batch mix } \\
\text { variability, CV2 to different run, same PCR batch variability, and CV3 to different run, different PCR batch } \\
\text { variability. }\end{array}$} \\
\hline
\end{tabular}

altogether) is a complex issue and has been discussed at length elsewhere. ${ }^{4}$ However, an emerging consensus is that molecular tests might be appropriate as stand alone tests for the group of women that are tested solely on the basis of maternal age or personal choice (this group constitutes the large majority of cases) and for which trisomies of chromosome 13, 18, and 21 and $\mathrm{XY}$ aneuploidies account for up to $99.9 \%$ of the disease associated abnormalities.

No one single molecular method seems to be obviously superior to the rest, since all have advantages and disadvantages. Our data suggest that PSQ is a robust, easy to interpret, and easy to set up method for the diagnosis of common aneuploidies, which should represent a very competitive alternative for widespread use in routine diagnostic laboratories.

\section{ACKNOWLEDGEMENTS}

We thank Dr A Reymond for discussions and critical advice concerning the manuscript, and Dr E Dermitzakis and Dr C Stella for advice on statistical treatment of the data. DNAs from trisomy 13, 18, and sex chromosome aneuploidies were kindly provided by Genzyme Genetics.

\section{ELECTRONIC-DATABASE INFORMATION}

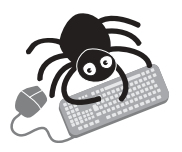

The URLs mentioned in this study are: http:// www.ensembl.org/ and www.biotage.com.

\section{Authors' affiliations \\ S Deutsch, U Choudhury, G Merla*, C Howald, S E Antonarakis, Department of Genetic Medicine and Development, University of Geneva Medical School, GE 1211, Geneva, Switzerland \\ A Sylvan, Biotage AB, Kungsgatan 76, Uppsala, Sweden}

*Present address: Servizio di Genetica Medica, IRCCS Casa Sollievo della Sofferenza, 71016 - San Giovanni Rotondo (FG), Italy.

This study was funded by grants from the Swiss National Science Foundation, the NCCR Frontiers in Genetics, the Child Care Foundation (to SEA) and a research grant from Pyrosequencing $A B$ (to SD and SEA). Conflict of interest: none declared.

\section{REFERENCES}

1 LeJeune J, Gautier M, Turpin R. Etudes des chromosomes somatiques de neufs enfants mongoliens. CR Acad Sci Paris 1959;248:1721-2.
2 Jacobs PA, Baikie AG, Court Brown WM, Strong JA. The somatic chromosomes in mongolism. Lancet 1959;1(7075):710.

3 Epstein CJ. Down syndrome (trisomy 21). In: Scriver CR, Beaudet AL, Sly WS, Valle D, eds. The Metabolic and molecular bases of inherited disease. New York: McGraw-Hill, 1995;749-94.

4 Hulten MA, Dhanjal S, Pert B. Rapid and simple prenatal diagnosis of common chromosome disorders: advantages and disadvantages of the molecular methods FISH and QF-PCR. Reproduction 2003;126(3):279-97.

5 Kuo WL, Tenjin H, Segraves R, Pinkel D, Golbus MS, Gray JW. Detection of aneuploidy involving chromosomes 13,18 , or 21 , by fluorescence in situ hybridization (FISH) to interphase and metaphase amniocytes. Am J Hum Genet 1991;49(1):112-9.

6 Verma L, Macdonald F, Leedham P, McConachie M, Dhanjal S, Hulten M. Rapid and simple prenatal DNA diagnosis of Down's syndrome. Lancet 1998;352(9121):9-12.

7 Pertl B, Yau SC, Sherlock J, Davies AF, Mathew CG, Adinolfi M. Rapid molecular method for prenatal detection of Down's syndrome. Lancet 1994;343(8907): 1 197-8.

8 Mann K, Fox SP, Abbs SJ, Yau SC, Scriven PN, Docherty Z, Ogilvie CM. Development and implementation of a new rapid aneuploidy diagnostic service within the UK National Health Service and implications for the future of prenatal diagnosis [see comment]. Lancet 2001;358(9287):1057-61.

9 Adinolfi M, Pertl B, Sherlock J. Rapid detection of aneuploidies by microsatellite and the quantitative fluorescent polymerase chain reaction. Prenat Diagn 1997;17(13):1299-311.

10 Lander ES, Linton LM, Birren B, Nusbaum C, Zody MC, Baldwin J, Devon K, Dewar K, Doyle M, FitzHugh W, Funke R, Gage D, Harris K, Heaford A, Howland J, Kann L, Lehoczky J, LeVine R, McEwan P, McKernan K, Meldrim J, Mesirov JP, Miranda C, Morris W, Naylor J, Raymond C, Rosetti M, Santos R, Sheridan A, Sougnez C, Stange-Thomann N, Stojanovic N, Subramanian A, Wyman D, Rogers J, Sulston J, Ainscough R, Beck S, Bentley D, Burton J, Clee C, Carter N, Coulson A, Deadman R, Deloukas P, Dunham A, Dunham I, Durbin R, French L, Grafham D, Gregory S, Hubbard T, Humphray S, Hunt A, Jones M, Lloyd C, McMurray A, Matthews L, Mercer S, Milne S, Mullikin JC, Mungall A, Plumb R, Ross M, Shownkeen R, Sims S, Waterston RH, Wilson RK, Hillier LW, McPherson JD, Marra MA, Mardis ER, Fulton LA, Chinwalla AT, Pepin KH, Gish WR, Chissoe SL, Wendl MC, Delehaunty KD, Miner TL, Delehaunty A, Kramer JB, Cook LL, Fulton RS, Johnson DL, Minx PJ, Clifton SW, Hawkins T, Branscomb E, Predki P, Richardson P, Wenning S, Slezak T, Doggett N, Cheng JF, Olsen A, Lucas S, Elkin C, Uberbacher E, Frazier M, Gibbs RA, Muzny DM, Scherer SE, Bouck JB, Sodergren EJ, Worley KC, Rives CM, Gorrell JH, Metzker ML, Naylor SL, Kucherlapati RS, Nelson DL, Weinstock GM, Sakaki Y, Fujiyama A, Hattori M, Yada T, Toyoda A, Itoh T, Kawagoe C, Watanabe H, Totoki Y, Taylor T, Weissenbach J, Heilig R, Saurin W, Artiguenave F, Brottier P, Bruls T, Pelletier E, Robert C, Wincker P, Smith DR, Doucette-Stamm L, Rubenfield M, Weinstock K, Lee HM, Dubois J, Rosenthal A, Platzer M, Nyakatura G, Taudien S, Rump A, Yang H, Yu J, Wang J, Huang G, Gu J, Hood L, Rowen L, Madan A, Qin S, Davis RW, Federspiel NA, Abola AP, Proctor MJ, Myers RM, Schmutz J, Dickson M, Grimwood J, Cox DR, Olson MV, Kaul R, Raymond C, Shimizu N, Kawasaki K, Minoshima S, Evans GA, Athanasiou M, Schultz R, Roe BA, Chen F, Pan H, Ramser J, Lehrach H, Reinhardt R, McCombie WR, de la Bastide M, Dedhia N, Blocker H, Hornischer K, Nordsiek G, Agarwala R, Aravind L, Bailey JA, Bateman A, Batzoglou S, Birney E, Bork P, Brown DG, Burge CB, Cerutti L, Chen HC, Church D, Clamp M, Copley RR, Doerks T, Eddy SR, Eichler EE, Furey TS, Galagan J, Gilbert JG, Harmon C, Hayashizaki Y, Haussler D, Hermjakob H, Hokamp K, Jang W, Johnson LS Jones TA, Kasif S, Kaspryzk A, Kennedy S, Kent WJ, Kitts P, Koonin EV, KorfI, Kulp D, Lancet D, Lowe TM, Mclysaght A, Mikkelsen T, Moran JV, Mulder N, Pollara VJ, Ponting CP, Schuler G, Schultz J, Slater G, Smit AF, Stupka E, Szustakowski J, Thierry-Mieg D, Thierry-Mieg J, Wagner L, Wallis J, Wheeler R, Williams A, Wolf YI, Wolfe KH, Yang SP, Yeh RF, Collins F, 
Guyer MS, Peterson J, Felsenfeld A, Wetterstrand KA, Patrinos A, Morgan MJ Szustakowki J, de Jong P, Catanese JJ, Osoegawa K, Shizuya H, Choi S, Chen YJ; International Human Genome Sequencing Consortium. Initial sequencing and analysis of the human genome [see comments]. Nature 2001:409(6822):860-921.

11 Venter JC, Adams MD, Myers EW, Li PW, Mural RJ, Sutton GG, Smith HO, Yandell M, Evans CA, Holt RA, Gocayne JD, Amanatides P, Ballew RM Huson DH, Wortman JR, Zhang Q, Kodira CD, Zheng XH, Chen L, Skupski M Subramanian G, Thomas PD, Zhang J, Gabor Miklos GL, Nelson C, Broder S, Clark AG, Nadeau J, McKusick VA, Zinder N, Levine AJ, Roberts RJ, Simon M, Slayman C, Hunkapiller M, Bolanos R, Delcher A, Dew I, Fasulo D, Flanigan M, Florea L, Halpern A, Hannenhalli S, Kravitz S, Levy S, Mobarry C, Reinert K, Remington K, Abu-Threideh J, Beasley E, Biddick K, Bonazzi V, Brandon R, Cargill M, Chandramouliswaran I, Charlab R, Chaturvedi K, Deng Z, Di Francesco V, Dunn P, Eilbeck K, Evangelista C, Gabrielian AE, Gan W, Ge W, Gong F, Gu Z, Guan P, Heiman TJ, Higgins ME, Ji RR, Ke Z, Ketchum KA, Lai Z, Lei Y, Li Z, Li J, Liang Y, Lin X, Lu F, Merkulov GV, Milshina N, Moore HM, Naik AK, Narayan VA, Neelam B, Nusskern D, Rusch DB, Salzberg S, Shao W, Shue B, Sun J, Wang Z, Wang A, Wang X, Wang J, Wei M, Wides R, Xiao C, Yan C, Yao A, Ye J, Zhan M, Zhang W, Zhang $\mathrm{H}$, Zhao Q, Zheng L, Zhong F, Zhong W, Zhu S, Zhao S, Gilbert D, Baumhueter S, Spier G, Carter C, Cravchik A, Woodage T, Ali F, An H, Awe A, Baldwin D, Baden H, Barnstead M, Barrow I, Beeson K, Busam D, Carver A, Center A, Cheng ML, Curry L, Danaher S, Davenport L, Desilets R, Dietz S, Dodson K, Doup L, Ferriera S, Garg N, Gluecksmann A, Hart B, Haynes J, Haynes C, Heiner C, Hadun S, Hostin D, Houck J, Howland T, Ibegwam C, Johnson J, Kalush F, Kline L, Koduru S, Love A, Mann F, May D, McCawley S, Mclntosh T, McMullen I, Moy M, Moy L, Murphy B, Nelson K, Pfannkoch C, Pratts E, Puri V, Qureshi H, Reardon M, Rodriguez R, Rogers YH, Romblad D, Ruhfel B, Scott R, Sitter C, Smallwood M, Stewart E, Strong R, Suh E, Thomas R, Tint NN, Tse S, Vech C, Wang G, Wetter J, Williams S, Williams M, Windsor S, Winn-Deen E, Wolfe K, Zaveri J, Zaveri K, Abril JF, Guigo R, Campbell MJ, Sjolander KV, Karlak B, Kejariwal A, Mi H, Lazareva B, Hatton T, Narechania A, Diemer K, Muruganujan A, Guo N, Sato S, Bafna V, Istrail S, Lippert R, Schwartz R, Walenz B, Yooseph S, Allen D, Basu A, Baxendale J, Blick L, Caminha M, Carnes-Stine J, Caulk P Chiang YH, Coyne M, Dahlke C, Mays A, Dombroski M, Donnelly M, Ely D, Esparham S, Fosler C, Gire H, Glanowski S, Glasser K, Glodek A, Gorokhov M, Graham K, Gropman B, Harris M, Heil J, Henderson S, Hoover J, Jennings D, Jordan C, Jordan J, Kasha J, Kagan L, Kraft C, Levitsky A, Lewis M, Liu X, Lopez J, Ma D, Majoros W, McDaniel J, Murphy S, Newman M, Nguyen T, Nguyen N, Nodell M, Pan S, Peck J, Peterson M Rowe W, Sanders R, Scott J, Simpson M, Smith T, Sprague A, Stockwell T, Turner R, Venter E, Wang M, Wen M, Wu D, Wu M, Xia A, Zandieh A, Zhu X. The sequence of the human genome. Science 2001;291(5507):1304-51.
12 Fletcher RHFS, Wagner EH. Clinical epidemiology: the essentials, 3rd ed. Baltimore: Williams and Wilkins, 1996.

13 Alderborn A, Kristofferson A, Hammerling U. Determination of singlenucleotide polymorphisms by real-time pyrophosphate DNA sequencing. Genome Res 2000;10(8):1249-58.

14 Deutsch S, Rideau A, Bochaton-Piallat ML, Merla G, Geinoz A, Gabbiani G, Schwede T, Matthes T, Antonarakis SE, Beris P. Asp1 424Asn MYH9 mutation results in an unstable protein responsible for the phenotypes in May-Hegglin anomaly/Fechtner syndrome. Blood 2003;102(2):529-34.

15 Hochberg EP, Miklos DB, Neuberg D, Eichner DA, McLaughlin SF, MattesRitz A, Alyea EP, Antin JH, Soiffer RJ, Ritz J. A novel rapid single nucleotide polymorphism (SNP)-based method for assessment of hematopoietic chimerism after allogeneic stem cell transplantation. Blood 2003;101(1):363-9.

16 Qiu P, Soder GJ, Sanfiorenzo VJ, Wang L, Greene JR, Fritz MA, Cai XY. Quantification of single nucleotide polymorphisms by automated DNA sequencing. Biochem Biophys Res Commun 2003;309(2):331-8.

17 Neve B, Froguel P, Corset L, Vaillant E, Vatin V, Boutin P. Rapid SNP allele frequency determination in genomic DNA pools by pyrosequencing. Biotechniques 2002;32(5): 1138-42.

18 Armour JA, Barton DE, Cockburn DJ, Taylor GR. The detection of large deletions or duplications in genomic DNA. Hum Mutat 2002;20(5):325-37.

19 Armour JA, Sismani C, Patsalis PC, Cross G. Measurement of locus copy number by hybridisation with amplifiable probes. Nucleic Acids Res 2000;28(2):605-9.

20 Slater HR, Bruno DL, Ren H, Pertile M, Schouten JP, Choo KHA. Rapid, high throughput prenatal detection of aneuploidy using a novel quantitative method (MLPA). J Med Genet 2003;40(12):907-12.

21 Schouten JP, McElgunn CJ, Waaijer R, Zwijnenburg D, Diepvens F, Pals G. Relative quantification of 40 nucleic acid sequences by multiplex ligationdependent probe amplification. Nucleic Acids Res 2002;30(12):e57.

22 Pertl B, Kopp S, Kroisel PM, Tului L, Brambati B, Adinolfi M. Rapid detection of chromosome aneuploidies by quantitative fluorescence PCR: first application on 247 chorionic villus samples. J Med Genet 1999;36(4):300-3.

23 Veltman JA, Schoenmakers EF, Eussen BH, Janssen I, Merkx G, van Cleef B, van Ravenswaaij CM, Brunner HG, Smeets D, van Kessel AG. Highthroughput analysis of subtelomeric chromosome rearrangements by use of array-based comparative genomic hybridization. Am J Hum Genet 2002;70(5): 1269-76

24 Snijders AM, Nowak N, Segraves R, Blackwood S, Brown N, Conroy J, Hamilton G, Hindle AK, Huey B, Kimura K, Law S, Myambo K, Palmer J, Ylstra B, Yue JP, Gray JW, Jain AN, Pinkel D, Albertson DG. Assembly of microarrays for genome-wide measurement of DNA copy number. Nat Genet $2001 ; 29(3): 263-4$

\section{$\mathrm{ECHO}$}

\section{Charcot-Marie-Tooth families in Japan with MPZ Thr124Met mutation}

\section{S Kurihara, Y Adachi, C Imai, H Araki, N Hattori, C Numakura, Y Lin, K Hayasaka, G Sobue, K Nakashima}

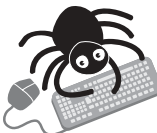

Please visit the Journal of Medical Genetics website [www. jmedgenet. com] for a link to the full text of this article.
Background: The MPZ Thrl24Met mutation is characterised by a late onset, pupillary abnormality, deafness, normal or moderate decreased motor nerve conduction velocity, and axonal damage in sural nerve biopsy.

Objective: To investigate the clinical manifestations of the axonal or demyelinating forms of the Japanese MPZ Thrl24Met mutation originating in four different areas: Tottori, Nara, Aichi, and Ibaragi.

Results: Genotyping with DNA microsatellite markers linked to the MPZ gene on chromosome 1q22-q23 showed shared allelic characteristics between $12.65 \mathrm{cM}$ and revealed a common haplotype in all Tottori families. Aichi and Ibaragi families shared parts of the haplotype around the MPZ gene. However, there was no consistency with a Nara family. Conclusions: The high frequency of this peculiar genotype in the Tottori CMT population is presumably due to a founder effect, but in Thrl24 it might constitute a mutation hotspot in the MPZ gene.

A Journal of Neurology, Neurosurgery, and Psychiatry 2004;75:1492-1494. 